NBER WORKING PAPER SERIES

\title{
ANNUITY PRICING IN PUBLIC PENSION PLANS: IMPORTANCE OF INTEREST RATES
}

\author{
Nino Abashidze \\ Robert L. Clark \\ Beth Ritter \\ David Vanderweide \\ Working Paper 25343 \\ http://www.nber.org/papers/w25343 \\ NATIONAL BUREAU OF ECONOMIC RESEARCH \\ 1050 Massachusetts Avenue \\ Cambridge, MA 02138 \\ December 2018
}

This research is funded, in part, by a grant from the Laura and John Arnold Foundation. The views expressed herein are those of the authors and do not necessarily reflect the views of the National Bureau of Economic Research.

At least one co-author has disclosed a financial relationship of potential relevance for this research. Further information is available online at http://www.nber.org/papers/w25343.ack

NBER working papers are circulated for discussion and comment purposes. They have not been peer-reviewed or been subject to the review by the NBER Board of Directors that accompanies official NBER publications.

(C) 2018 by Nino Abashidze, Robert L. Clark, Beth Ritter, and David Vanderweide. All rights reserved. Short sections of text, not to exceed two paragraphs, may be quoted without explicit permission provided that full credit, including $\odot$ notice, is given to the source. 
Annuity Pricing in Public Pension Plans: Importance of Interest Rates

Nino Abashidze, Robert L. Clark, Beth Ritter, and David Vanderweide

NBER Working Paper No. 25343

December 2018

JEL No. H7,J26,J45

\section{$\underline{\text { ABSTRACT }}$}

There is little systematic information on the distribution options in public sector retirement plans and how annuity options are priced relative to the standard single life annuity. This study examines the distribution options of 85 large public retirement plans covering general state employees, teachers, and local government employees. An important component of the analysis is the construction of a data set presenting the annuity options offered by each of these plans and how the monthly benefits for these distribution options are priced. The analysis shows that interest rates used to price annuities vary considerably across the plans. As a result, retirees with the same monthly benefit if a single life benefit is chosen will have substantially different monthly benefits if they select the joint and survivor annuity offered by their retirement plan.

Nino Abashidze

Department of Economics

North Carolina State University

Raleigh, NC 27695

nabashi@ncsu.edu

Robert L. Clark

Poole College of Management

Box 7229

North Carolina State University

Raleigh, NC 27695

and NBER

robert_clark@ncsu.edu

\author{
Beth Ritter \\ Department of Management, \\ Innovation, and Entrepreneurship \\ North Carolina State University \\ bmritte2@ncsu.edu \\ David Vanderweide \\ Fiscal Analyst \\ Fiscal Research Division \\ North Carolina General Assembly \\ Raleigh, NC 27601 \\ david.vanderweide@ncleg.net
}


State and local retirement plans differ from employer-provided pension plans in the private sector in several important ways. First, virtually all full-time public employees are covered by a pension plan in which they are required to participate. Second, defined benefit plans remain the dominant plan type for state and local pensions. Third, public plans are exempt from almost all provisions of the Employee Retirement Income Security Act (ERISA) which regulates most aspects of private retirement plans. As a result, government agencies are able to set most provisions of their plans without the constraints imposed by ERISA.

There is little systematic information on several important aspects of key provisions of state and local retirement plans and how these plan characteristics affect retirement income of public employees. This study examines the distribution options of 85 large public retirement plans covering general state employees, teachers, and local government employees. ${ }^{1}$ An important component of the analysis is construction of a data set presenting the annuity options offered by each of these plans and how the monthly benefits for these distribution options are priced.

The following discussion shows considerable variation in these important plan characteristics. Differences in the interest rates used to convert one benefit option to another result in substantial differences in the monthly benefit for retirees with similar career histories from one state to another. An important policy question is whether the variation in monthly benefits across state and local retirement systems due to using different interest rates affects the proportion of retirees who select a J\&S annuity.

\footnotetext{
${ }^{1}$ Periodic reports by the Wisconsin Legislative Council describe the main provisions of these 85 plans. The most recent report was released in 2016 and covers plans in 2015. https://docs.legis.wisconsin.gov/misc/lc/comparative_retirement_study/2015_retirement.pdf
} 


\section{Distribution of Public Pensions by Plan Type}

There has been a major shift in the incidence of retirement plans in the private sector over the past four decades as employers eliminated defined benefit (DB) plans and established new defined contribution (DC) plans, typically 401(k) plans. ${ }^{2}$ In contrast, DB plans remain the dominate form of retirement plans in the public sector. However, in recent years, there has been a trend by public pension systems toward offering cash balance and hybrid plans and some states now allow employees to select the type of plan that best suits their needs and preferences.

Chart 1 classifies the 85 retirement systems in our sample into the types of retirement plans offered to newly-hired employees. Many public retirement systems have made substantial changes to their plans that have reduced the generosity of benefits to future employees. Throughout this study, we examine the plans available to new employees. The chart shows that 59 systems offer only traditional DB plans while the other 26 public plans offer other types of retirement plans to their employees or allow employees to select their preferred type of retirement plan.

\section{[Chart 1]}

While 69 percent of the plans in our sample continue to offer only a traditional DB plan as the only mandatory plan, there have been significant changes by a number of state and local retirement systems in the type of plan offered to new employees. Five systems now offer only cash balance plans. Cash balance plans are a form of a DB plan but these plans indicate the

\footnotetext{
${ }^{2}$ The most common DC plan offered by firms in the private sector is a 401(k) plan. While many public employers can offer 401(k) plans, they also offer 457 plans. In addition, school districts organizations often offer 403(b) plans. In general, these plans are provided as supplemental retirement plans alongside of a mandatory pension plan. Clark, Pathak, and Pelletier (2018 forthcoming) provide a detailed discussion of these plan types.
} 
value of an employee's account balances. ${ }^{3}$ Instead of a benefit formula that is used in a traditional DB plan, cash balance plans provide a notional account for each participant, specify a monthly contribution to the balance, and promise a return on the account balance. At retirement, the account balance can be converted into an annuity (either single life or J\&S) using mortality rates and an assumed interest rate.

Six additional systems offer only hybrid plans. In general, hybrid plans include mandatory coverage by both a DB and DC plan. The DB component of hybrid plans is typically less generous compared to the benefit of systems that offer only a traditional DB plan. Required participation in the DC component increases the value of total retirement benefit. Twelve systems offer employees the option of selecting the type of pension they prefer with options being either DB, DC, or hybrid plans. In general, the DB plans offered as an option by these systems are similar to the plans offered by systems that offer only a traditional DB plan. All of these DB plans offer similar annuity options to their retirees and thus will be included in our examination of the pricing of J\&S benefits discussed below. Finally, three systems offer only DC plans. ${ }^{4}$ We will review the distribution options offered by these systems along with the systems with a DC option as a choice.

Distribution options vary by the type of retirement plan. All the traditional DB plans specify a benefit formula that determines a lifetime monthly benefit for the retiree. These plans then offer a J\&S benefit that results in a lower monthly benefit compared to the single life

\footnotetext{
${ }^{3}$ McGill, et al (2010, page 381-383) provide a description of cash balance plans and how they are managed. Also see Clark and Schieber (2004) for a discussion of the adoption of cash balance plans by firms.

${ }^{4}$ Alaska PERS and TRS DC plans are both 401(k) plans while the Michigan SERS includes both a 401(k) and a 457 plan.
} 
benefit with the reduction being determined by mortality rates and an interest rate. In contrast, DC and cash balance plans have account balances which are available to retirees in a lump sum. In cash balance plans, retirees are able to request an annuity. In this case, the monthly benefit is determined by converting the account balance into a single life or $J \& S$ benefit with the same present value. DC plans often allow workers the opportunity to annuitize with an insurance company selected by the retirement system. The DB and DC components of hybrid plans provide the same distribution options as described above.

Some public retirement plans also offer retirees the option of taking a lump sum distribution instead of a life annuity. Prior research, focusing primarily on choices by retirees in private sector plans, has explored the tendency of individuals to under-annuitize wealth. ${ }^{5}$ In sharp contrast to pension distributions chosen by private sector workers, retirees in the public sector rarely select lump sum distributions because of the way they are typically priced. In most public plans, the lump sum is based solely on employee contributions plus some accrued interest rate, which is typically much less than the present value of the life annuity.

\section{Annuity Options in State and Local Retirement Plans}

In this section, we review the distribution options offered by each of the plan types described above. Given the changes in the generosity of public retirement plans, many systems have several tiers of their plans that cover workers hired in different time periods. However, as noted earlier, our analysis focuses only on the plans covering newly hired employees. The analysis begins with an overview of the distribution options offered by retirement systems with

\footnotetext{
${ }^{5}$ For example, see Benatzi, Previtero, and Thaler 2011; Brown et al. 2008; Brown 2001; Chalmers and Reuter 2012; and Butler and Teppa 2007.
} 
only a traditional DB plan. Plan documents typically provide detailed information on how the monthly benefit for the retiree is determined. In most cases, the benefit formula indicates the retirement benefit for a retiree and this benefit ends with the death of the retiree. This is a single life annuity and provides the maximum monthly benefit available to a retiree. Many plans provide some variant of this life annuity to insure that retirees and their beneficiaries at least receive their own contributions back in retirement or at their death. The return of contributions can be in the form of a lump sum payout if the annuitant dies before the value of benefits paid reach the present value of the employee's lifetime contributions plus credited interest. In the following analysis, we classify all of these payout options as being a single life annuity.

All of these plans then offer additional annuity options that the retiree may select. The monthly benefit for other options is determined in a manner that keeps the present value of the benefits the same to the system regardless of which option is chosen. Next, we examine the annuity options offered by cash balance plans, DB parts of hybrid plans, and the DB plans offered by state systems that allow workers a choice among plan types. The annuity options for each plan type is taken from documents on the webpages of the retirement systems. ${ }^{6}$

\section{Distribution Options in DB Only Retirement Systems}

Defined benefit pension plans typically have a benefit formula that specifies a monthly retirement benefit that a retiree will receive from retirement until death, i.e. a single life annuity. Most DB plans also offer other distribution options such as joint and survivorship annuities (J\&S) which promise a benefit for the life of the retiree and the designated beneficiary, typically

\footnotetext{
${ }^{6}$ We have constructed a web page for this research project that provides comprehensive information on the distributions offered by each retirement system. The information on plan type and distribution options was found on the websites of each retirement system: https://retirement.wordpress.ncsu.edu/
} 
a spouse. Public retirement systems also offer lump sum distributions; however, as mentioned above, these distributions typically are based only on employee contributions plus some specified interest rate. Unlike retirees in the private sector, public employees rarely request lump sum distributions once they are eligible to immediately begin a retirement annuity (Clark, Morrill, and Vanderweide, 2014).

A key question is how are the monthly benefits for the other options calculated? Specifically, what is the monthly benefit for a retiree who selects the J\&S option in order to provide continuing retirement income to a beneficiary after the death of the retiree? In general, plan sponsors state that the system offers J\&S benefits that have the same present value as the single life annuity based on the benefit formula. In order to calculate the J\&S benefit with the same present value as the single life annuity, retirement systems use appropriate mortality rates (or life tables) to determine the expected payments over the lives of the retiree and their beneficiary and an interest rate to convert the monthly flow of benefits into a present discounted value. Since the expected payout period is longer for the J\&S annuity, the monthly benefit will be lower than the benefit for retirees who decline the J\&S option.

All public retirement plans in our sample offer $J \& S$ annuities to their retirees with most plans providing several J\&S options based on the amount of the monthly benefit after the retiree dies. The most common options are a 100 percent and 50 percent of the benefit that was received when the retiree was alive. If a retiree selects a 100 percent J\&S annuity, the monthly benefit is the same before and after the retiree dies while a 50 percent $\mathrm{J} \& \mathrm{~S}$ results in the beneficiary receiving a benefit that is half the monthly amount while the retiree was alive. The 100 percent option results in a lower monthly benefit while the retiree is living compared to the 50 percent option. Some plans allow for other specified percent that is paid to the beneficiary 
and still others allow the retiree to select the level of benefit that will be paid to the beneficiary. Still others also provide options that are called J\&S pop-up annuities. These options provide an increase in the retiree's benefit if the beneficiary dies first. Each of the annuity options for each of the plans in our study can be found at https://drive.google.com/file/d/1UwKYbhFrAWxvwu_Db2oOgh5gHUb98kR_view.

The retirement systems typically price each of these options so they have the same present value to the system given the assumed interest rate.

Private sector DB plans are covered by ERISA which requires that J\&S benefits be offered and that they be the default option for pension participants. ${ }^{7}$ ERISA also specifies the market interest rates that must be used in the $\mathrm{J} \& \mathrm{~S}$ calculations and appropriate mortality tables. Federal regulations ${ }^{8}$ specify that the interest rates established by the Commissioner of Internal Revenue must be based on yields on corporate bonds of the top three quality levels. As of September 2018, those interest rates were 3.21 percent for the first 5 years, 4.26 percent for years 5 to 20 , and 4.55 percent after 20 years.

In contrast to private sector DB plans, public sector DB plans are not covered by ERISA and thus state and local plans are not required to have a J\&S benefit as the default distribution

\footnotetext{
${ }^{7}$ The initial 1974 ERISA legislation required that pension plans offer at least a 50 percent J\&S annuity and that it be the default distribution option in the plan; however, retirees could simply request a single life annuity when claiming benefits. The Retirement Equity Act of 1984 required a spouse to sign a notarized consent form waiving her right to the $J \& S$ before the retiree could receive a single life annuity. This requirement seems to have a significant impact on the incidence of retirees selecting a J\&S annuity (Holden and Nicholson, 1998; Johnson, Uccello, and Goldwyn, 2005). See Part 4, Chapter 72, Section 9 of the Internal Revenue Manual for further detail on current law: https://www.irs.gov/irm/part4/irm 04$\underline{072-009}$.

826 CFR 1.430(h)(2)-1(d)
} 
option. ${ }^{9}$ Therefore, state and local governments have considerable discretion concerning the provisions of their pension plans. Of particular interest for this study is that public retirement plans are free to select the interest rate used to convert the single life annuity to a J\&S benefit. While there is considerable diversity across state and local retirement systems, most public plans use the same interest rate that the plan assumes it will earn on its investment portfolio. These assumed rates of return vary widely across states and are considerably higher than the market interest rates required by ERISA to calculate minimum J\&S benefits. Chart 2 shows the number of plans that offer each of the various annuity options available to retirees in each of these plans. ${ }^{10}$

\section{[Chart 2]}

Along with a single life and $J \& S$ annuity options discussed above, most systems also offer "other" annuity options that include guaranteed payments for a certain number of years even if the retiree dies. ${ }^{11} \mathrm{~A}$ less common option is a single life annuity called Social Security Leveling which allows retirees to have a higher pension benefit before claiming Social Security benefits in exchange for a lower benefit after claiming. Clark et al (2018) provide a detailed discussion of the leveling annuity and its effect on benefits before and after the age of claiming Social Security benefits. Finally, some retirement systems provide a partial lump sum payment option, which allows retirees to take a portion of their retirement income in a lump sum payment

\footnotetext{
${ }^{9}$ While state and local plans are not covered by ERISA, some public plans have adopted the requirement that a $\mathrm{J} \& \mathrm{~S}$ is the first option so that retirees need to consult with their spouses.

${ }^{10}$ Appendix Table 1 lists each of the 59 plans and the annuity options offered by that plan.

11 "Other” annuity category also includes the "last survivor option" that provides the reduced retirement benefits to the last survivor. The Idaho retirement system provides modified Social Security Leveling option which allows retirees to combine Social Security Leveling option with either $100 \%$ or 50 \% J\&S option. These modified options are also classified as “other” annuity category.
} 
at the time of retirement. The amount of partial lump sum payment differs across retirement systems and usually ranges from 36 months (Arizona SRS) to 60 months (Arkansas PERS) of single life annuity benefit.

\section{Distribution Options in Other Defined Benefit Plan Types}

Besides the 59 retirement systems that offer only traditional defined benefit plans, 23 other systems offer some version of a DB plan (cash balance or hybrid plans) or choice of several pension options. Chart 3 illustrates the annuity options offered by these plans. The annuity options for these plans mirrors those offered by systems with only traditional DB plans. All plans offer some type of J\&S annuity and a slightly higher proportion of these plans include a Social Security Leveling option. The details of these options can be found at https://drive.google.com/file/d/1UwKYbhFrAWxvwu_Db20Ogh5gHUb98kR_/view

[Chart 3]

\section{Distribution Options in Defined Contribution Plans}

Three systems (Alaska PERS and TRS and Michigan SERS) offer only defined contribution plans to their members while nine additional systems include a DC option as a choice to newly hired employees (see Table 1). Each of the DC only systems allow retirees to annuitize with the financial service company that manages the retirement accounts. Several of the DC choice systems have a similar arrangement while it appears that other systems offer annuity options within the system (Ohio PERS and STRS and Michigan MERS) and Utah SRS just allows the retiree to withdraw their funds. In addition, each DC plan allows retirees to leave funds in the system, roll over funds to another account, or either fully or partially withdraw funds in periodic installments including monthly, quarterly, semi-annually, or annually.

[Table 1] 


\section{Calculating J\&S Annuities}

The benefit formula in DB plans indicates the monthly retirement benefit that a retiree would receive from claiming until death. This benefit is a single life annuity as benefits cease with the death of the retiree. Once a worker has satisfied the conditions for unreduced retirement, the monthly benefit is not a function of age. Thus, holding career variables constant, individuals retiring at younger ages will receive greater lifetime benefits.

The stated objective of most retirement systems is to offer a menu of annuity options that are present value neutral from the perspective of the system. The first step in determining the monthly benefit for other annuity options is the calculation of the expected present value of the single life annuity. First, define PV[A] to be the present value of a \$1 per year benefit payable at the end of each year for the life of an individual age A, the formula for which can be written as:

$$
P V[A]=\sum_{a=A+1}^{120} \frac{\text { Survival }}{\left(1+r_{i}\right)^{a-A}}
$$

where Survival is the probability of survival from age A to age a and $r_{i}$ is the assumed interest rate. As benefits are almost always paid in equal monthly installments, a small further adjustment would be made to reflect monthly payment of benefits using one of several standard methods. Then the present value of the monthly single life benefit, BsL, can be written as:

$$
P V_{S L}[A]=B_{S L} * 12 * P V[A]
$$

This calculation is usually based on the mortality experience of the system and the assumed rate of return on the pension fund. Having calculated the present value of the single life benefit, the retirement system then calculates a monthly benefit for the other annuity options using the same basic assumptions. 
Most states provide several J\&S options. Retirees that select one of these J\&S options are exchanging lower monthly benefits for the continuation of benefits after their death as benefits will continue to be paid to the designated survivor until his or her death. For the present value of this annuity to be the same as that of the single life benefit, monthly benefits must be lower. The price of this insurance for a lifetime survivor benefit, or the magnitude of the reduction in monthly benefits, depends on the age of the retiree and the age of the beneficiary. To calculate the present value of the J\&S benefit, first define the present value of a \$1 per year benefit payable at the end of each year if and only if both annuitants are living:

$$
P V_{\text {Joint }}[A, S]=\left(\sum_{a=A+1, s=S+1}^{a=120, s=120} \frac{\text { Survival }_{A, S}^{a, s}}{\left(1+r_{i}\right)^{a-A}}\right)
$$

where Survival is the joint probability of the retiree surviving from age A to age a and the spouse surviving from age S to age s. As with PV[A], a small adjustment would be made to reflect payment in equal monthly installments. Then the present value of the monthly J\&S benefit, $\mathrm{B}_{\mathrm{J} \& \mathrm{~S}}$, can be written as:

$$
P V_{J \& S}[A, S]=B_{J \& S} * 12 *\left[P V[A]+P c t J \& S *\left(P V[S]-P V_{\text {Joint }}[A, S]\right)\right]
$$

PctJ\&S indicates the percent of the initial benefit when both the retiree and beneficiary are alive that continues after the death of the retiree. As the equations show, the interest rate is an important component in converting the single life annuity into a J\&S benefit. Similar calculations are made to determine the monthly benefit of each annuity option. Many states provide retirees with on-line calculators that show the monthly benefits for the various annuity options given their employment and earnings history. In the next section, we present data acquired from the retirement systems on the interest rate used to determine the monthly benefits for those retirees selecting a benefit option other than the single life annuity. 


\section{Pricing of J\&S Benefits}

In order to assess the magnitude of the reduction in monthly benefits for the J\&S option relative to the single life annuity, one must know the interest rate used by the retirement system. There is no systematic data on interest rates used by public retirement plans in the pricing of J\&S annuities. On-line documents such as employee handbooks and financial documents describe retirement plans and distribution options. Most plans also have on-line calculators that allow employees to convert a single life annuity into a J\&S benefit if they login or enter their personal earnings history, service, age, and the age of their beneficiary. However, plan documents rarely describe the actual process and assumptions behind how J\&S options are priced. In this section, we first present information from our data collection effort and then illustrate how different interest rates affect the money benefit for the J\&S annuity.

\section{Pricing of J\&S Annuity Varies Widely Across the Retirement Systems}

In an effort to uncover the interest rates used by public retirement systems, we contacted each of the 85 retirement systems in our sample and requested information on how various distribution options are priced. Our informational search included e-mails, telephone calls, and freedom of information faxes. ${ }^{12}$ Some retirement systems specifically declined to provide the requested information on the interest rate used to calculate J\&S benefit. Despite repeated efforts and requests using alternative methods of communication, some systems failed to respond at all.

\footnotetext{
${ }^{12} \mathrm{~A}$ detailed review of our contacts with the retirement systems is available on the project website, https://retirement.wordpress.ncsu.edu/directory/
} 
Typically, systems state that benefits for other distribution options should have the same expected present value as the single life annuity specified by the plan for the retiree; however, most plans do not publicly disclose the interest rate used to determine the present value of the annuity options. After a year of contacting and re-contacting retirement systems, we have obtained annuity pricing information for 64 retirement systems including 44 of the 59 plans with only traditional DB plans. Table 2 lists the interest rates used by each of the systems with only a traditional DB plan while Chart 4 sorts plans by the interest rate used by systems. The Idaho PERS retirement system and the Delaware SEPP retirement system provide J\&S coverage for beneficiaries without reducing the monthly benefit compared to the single life benefit as specified by the formula.

[Table 2]

\section{[Chart 4]}

Most of the retirement systems use the same interest rate for these annuity calculations as the assumed rate of return of their investment portfolio. These rates vary from 6.75 percent to over 8 percent. It is interesting to note that the range of rates for the public retirement plans is higher than those current rates required of ERISA plans and until this study peer plan data has not been available for retirement plans to benchmark. Table 2 shows the interest rate used to determine the J\&S benefit along with the assumed rate of return for each of the plans. Table 3 and Chart 5 provide similar information for retirement systems with hybrid plans and cash balance plans along with the systems that allow employees to select which type of retirement plan they prefer. The interest rates used by these plans are in the same range as shown for DB only retirement systems in Table 2. Of note are a few plans that do not use the assumed rate of return as the interest rate in their J\&S calculations. Maryland SRPR uses the 25th percentile of 
the expected rate of return to determine their rate. This was set in such a way so that $75 \%$ of the time the rate will meet or exceed the expected rate of return. Delaware SEPP uses several rates that vary with the survivor option and had no relationship to the rate of return. Also, three plans use a rate that includes the impact of post retirement increases or a COLA. (Cost of Living adjustment)

[Table 3]

[Chart 5]

\section{Impact of Interest Rates on J\&S Monthly Benefits}

The impact of using different interest rates on the monthly J\&S benefit depends significantly on the probability of the designated survivor outliving the retiree. Large public retirement systems typically use the mortality experience of their own participants. In this analysis, we calculate monthly J\&S benefits using mortality tables in the calculation that reflect typical public-sector mortality experience. ${ }^{13}$ While the published tables are gender-specific, each system would calculate benefits using the overall gender distribution of the system's participants, not the genders of the individual retiree and beneficiary, because public retirement systems are

\footnotetext{
${ }^{13}$ We used tables published by the Society of Actuaries in "Exposure Draft: Pub-2010 Public Retirement Plans Mortality Tables Report” (https://www.soa.org/experience-studies/2018/pub-2010retirement-plans/), published in August 2018. These tables were developed using the data of 78 public plans across the U.S. during the years 2008-2013.
} 
required to use a gender-neutral calculation for converting forms of payment. ${ }^{14}$ For illustration, we assume that the single life retired worker monthly benefit is $\$ 1,000$.

Table 4 shows examples of the J\&S monthly benefit that would be payable if the retirement system uses the mortality experience described above. Panels A and B both assume the plan has a teacher population that is 65 percent female which results in longer life expectancies compared to populations that have a higher percentage of males. On average, many women are married to older men and thus, their designated survivors are less likely to outlive them. Panel A uses an interest rate of 8 percent, the highest rate shown in the sample in Table 2, and Panel B uses an interest rate of 4 percent, the lowest rate shown in the sample.

\section{[Table 4]}

To begin, we assume that the retiree and the beneficiary are both age 60 when the benefit is initially claimed. Using an interest rate of 8 percent to calculate the J\&S annuity (Panel A), the monthly J\&S benefit is $\$ 941$ or $\$ 59$ per month less that the single life annuity. In other words, for the cost of $\$ 59$ per month, the retiree can insure that their beneficiary will continue to receive a benefit even after the retiree dies. The magnitude of the benefit reduction increases for each year the beneficiary is younger than the retiree and declines for each year they are older than the retiree. If the beneficiary is age 50 and the retiree is age 60 , the monthly $\mathrm{J} \& \mathrm{~S}$ benefit is only $\$ 914$. Thus, the cost of insuring that the beneficiary will continue to receive a retirement benefit after the death of the retiree is $\$ 86$ per month.

Now consider the benefits shown in Panel B when the retirement system uses an interest rate of 4 percent to determine the $J \& S$ monthly benefit. For the individuals who are both age 60

\footnotetext{
${ }^{14}$ Based on the Supreme Court's ruling in Arizona Governing Committee v. Norris.
} 
at the time of claiming the retirement benefit, the monthly J\&S benefit is $\$ 914$ per month indicating that selecting a J\&S benefit lowers the monthly benefit by $\$ 86$. The benefit using a 4 percent interest rate is $\$ 27$ lower than if the system used an 8 percent rate. The biggest difference in the monthly benefit amounts between the two panels occurs for the age combinations where the designated survivor is most likely to outlive the retiree, for example a 70 year old retiree and a 50 year old designated survivor. In this case, the monthly J\&S benefit using a 4 percent interest rate is $\$ 103$ lower than the $\mathrm{J} \& S$ benefit using an 8 percent rate.

The proportion of women in public employment is much lower in occupations outside of teaching. As a result, the mortality experience used by a retirement system that does not cover teachers is considerably different and this difference in life expectancy magnifies the benefit reduction associated with selecting a J\&S benefit. Consider these same calculations for the J\&S benefit using the mortality experience for public safety workers that is only 10 percent female. Panels A and B, Table 5 show the monthly J\&S benefit for this population using 8 and 4 percent interest rates. Panel A calculates the J\&S benefit using an interest rate of 8 percent, the same as Panel A, Table 4, and Panel B uses an interest rate of 4 percent, the same as Panel B, Table 4.

\section{[Table 5]}

Because the population in these panels has a higher proportion of male retirees (and therefore a higher percentage of beneficiaries are female) it is more likely compared to many other public-sector retiree groups for the retiree to be outlived by their designated beneficiaries. Thus, the differences in benefit amounts using a 4 percent compared to an 8 percent interest rate (compare Panel A to Panel B) are larger than the differences in benefit amounts shown in Table 4. The monthly benefits in Panel A are for a public safety worker using an 8 percent interest rate. For an individual retiring at age 60 with a spouse who is also age 60 , the monthly J\&S 
benefit is only be $\$ 896$ or a reduction of the monthly benefit of $\$ 104$ relative to the single life benefit. Using the mortality experience of public school employees, the reduction in the monthly benefit was only $\$ 59$ in the previous example.

These calculations highlight the role of the assumed interest rate in determining the benefit reduction associated with selecting a J\&S benefit. Lower interest rates imply larger cost to the retiree in the form of lower monthly benefits from choosing a J\&S benefit compared to the single life annuity.

\section{Does the Price of J\&S Annuity Matter?}

As we have shown, most public employees continue to be covered by defined benefit pension plans. These plans include a formula that indicates the monthly benefit that an individual can receive when they claim a retirement benefit. Typically, retirement benefits will cease when the retiree dies. The decision of which annuity to select at retirement is a difficult and complex decision (Brown and Poterba, 2000; Aura, 2005; Clark, Hammond, and Vanderweide, 2019). If the retiree wishes to provide a benefit that continues for the life of their beneficiary, retirement systems allow participants to select a J\&S benefit at the cost of lower monthly benefits. The choice of an annuity is influenced by many personal and household factors the most important of which is the presence of a spouse or partner. This decision will influence well-being throughout the retirement years of the retiree and the potential beneficiary.

Retirees are typically faced with a menu of distribution options; however, the primary or first level decision is whether the retiree wants a single life annuity that ends with her death or whether she wishes to provide a continuing benefit to a designated beneficiary, usually a spouse. The most important factor influencing the decision to select a J\&S benefit is the presence of 
spouse. While plans usually do not limit beneficiaries in J\&S annuities to spouses, the typical case is that the retiree names their spouse as the beneficiary when selecting a $J \& S$ annuity.

The work history of the spouse will likely influence the annuity choice. If the spouse has been a career worker and expects to receive a pension, the retiree may consider this future income and be less likely to request a J\&S benefit since the spouse will receive a pension after the death of the retiree even if the retiree selects the single life annuity. Other employerprovided benefits earned by the spouse such as retiree health insurance should also affect the choice of an annuity.

The public sector workforce has a higher percentage of females compared to the entire US labor force. As such, we might expect some different patterns of annuity choices by retirees from state and local retirement plans. Clark, Hammond, and Vanderweide (2019) found that among retirees in North Carolina, men are much more likely to choose a J\&S annuity compared to women (61 Percent compared to only 35 percent). The difference in the proportion of women selecting J\&S probably reflects the fact that women have lower age specific mortality rates and are more likely to outlive their spouse. We should also note that gender is highly correlated with many of the other variables that affect annuity choice such as the work history of their spouse.

Retirees will be more likely to choose a J\&S annuity if they have low life expectancy and are married to spouses with high life expectancy, holding age constant. Thus, the health of both the retiree and the potential beneficiary enter into the decision making of which annuity to accept. Higher levels of wealth may influence the annuity choice as households with greater wealth have greater liquidity and hence more options in how to finance future consumption. Individuals with higher personal discount rates place greater value on money in the early retirement years. Thus, they are expected to favor a single life annuity instead of a J\&S annuity. 
The primary unanswered question for this paper is whether the pricing of J\&S annuities as measured by the use of alternative interest rates affects the probability of retirees choosing a J\&S benefit over a single life annuity. Our data collection effort has shown that the interest rates used by public retirement plans vary substantially. This variation means that holding constant the monthly benefit for a single life annuity, the J\&S monthly benefit is much smaller for retirees in states that have use lower interest rates. In the previous section, we showed that this reduction in monthly benefit (holding the interest rate constant) can be in the range of 5 to 10 percent for retirees and beneficiaries who are about the same age to 30 percent when the beneficiary is much younger than the retiree.

In 2016, the Treasurer of North Carolina sent a request to the state treasurers of all states asking for information on the percentage of recent retirees who selected various pension options (Clark and Cowell, 2017). Nine states covering 12 retirement systems responded to her request for this information. Table 6 reports the responses showing the proportion of retirees selecting a $J \& S$ benefit along with the interest rates used by the systems to calculate the J\&S monthly benefit. This small sample provides no indication that the interest rate and hence the reduction in monthly benefit influences the proportion of retirees selecting a J\&S annuity. All but two of the systems used an interest rate between 7.0 and 7.75 percent. Using these data, there is no indication that systems using lower interest rates have a lower proportion of retirees choosing a J\&S benefit.

[Table 6]

The impact of lower interest rates on J\&S benefits and the resulting proportion of individuals opting for a J\&S over the single life annuity deserves additional study. Public retirement systems are gradually lowering their assumed rate of return on their assets. Since most systems use the assumed rate of return as the interest rate in the annuity calculates, this 
trend will result in lower monthly benefits for retirees selecting the J\&S benefit. It is important to determine how these changes will impact the proportion of retirees selecting the J\&S benefit. 


\section{Chart 1. State and Local Pensions by Type of Plan}

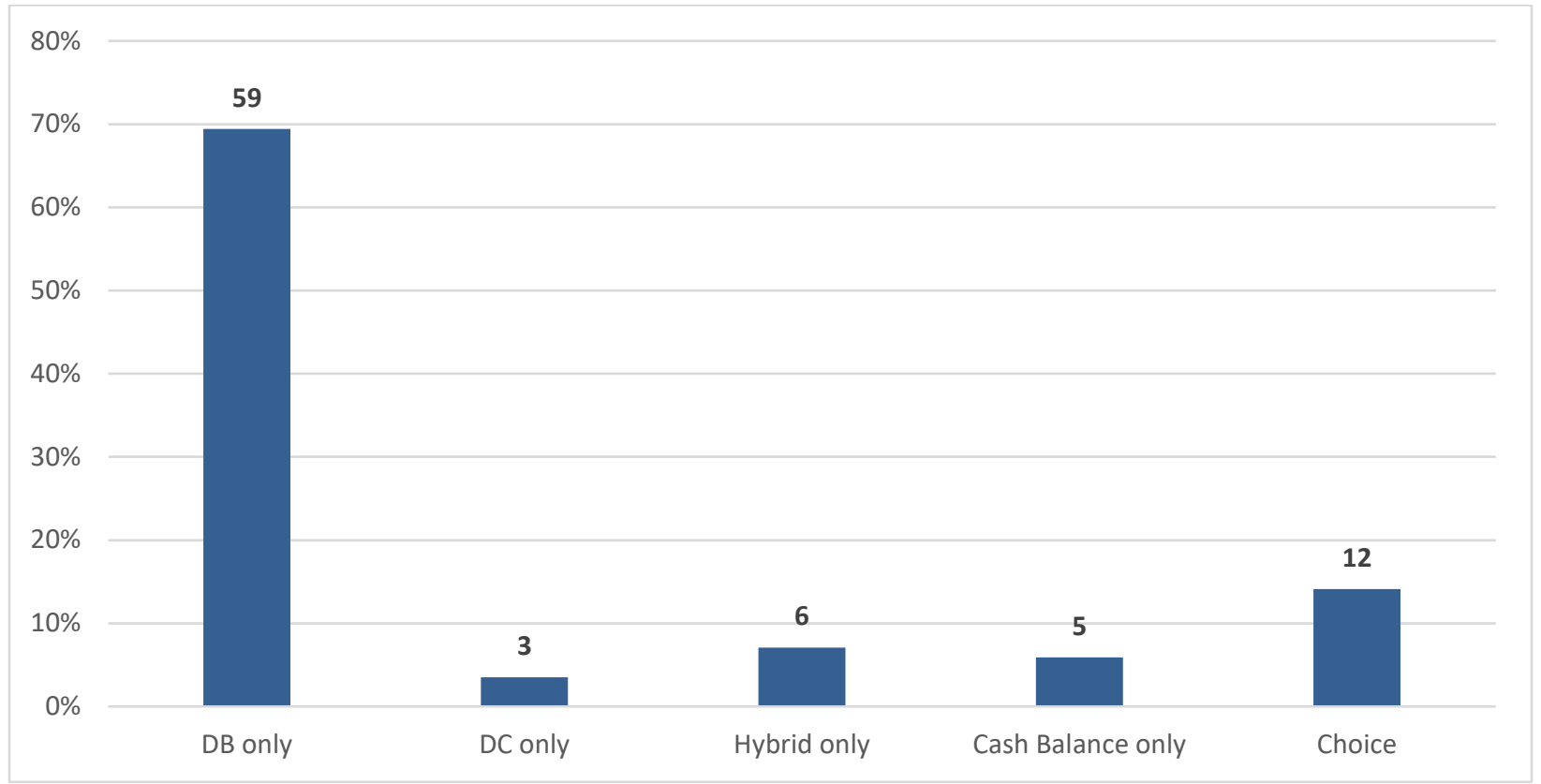

The 85 retirement systems examined in this study are the plans that are reviewed periodically by Wisconsin Legislative Council. The most recent report was released in 2016 and covers plans in 2015.

https://docs.legis.wisconsin.gov/misc/lc/comparative_retirement_study/2015_retirement.pdf

The authors reviewed the websites of each of these public plans. The data in the chart are based on this review. Information on type of plan offered by each retirement system is shown on our project website:

https://drive.google.com/file/d/1UwKYbhFrAWxvwu_Db2oOgh5gHUb98kR_view 
Chart 2. Annuity Options Provided by State and Local Plans Offering Only Traditional DB Plans

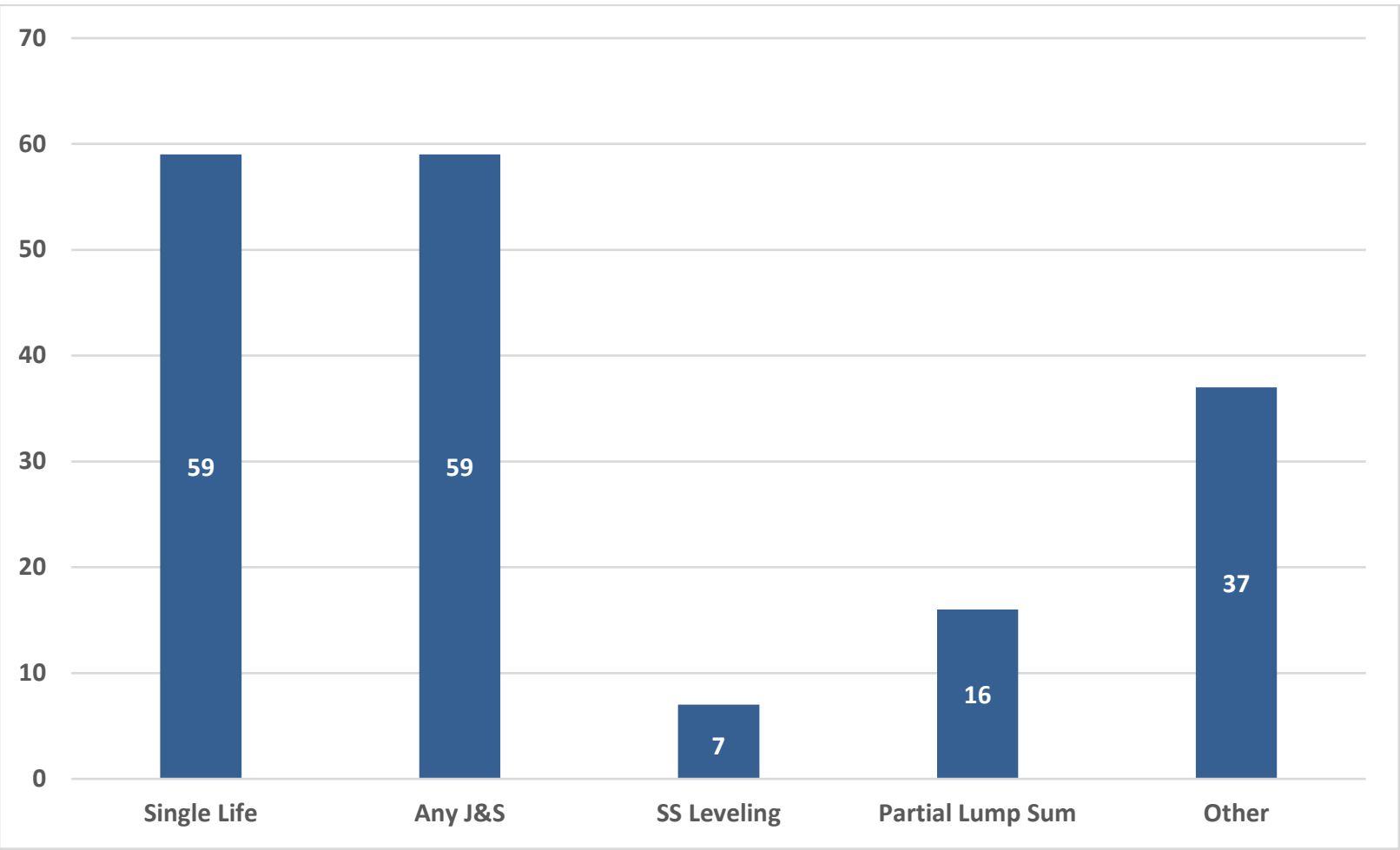

Source: Plan documents describing annuity options are summarized at:

https://drive.google.com/file/d/1UwKYbhFrAWxvwu_Db2oOgh5gHUb98kR_/view

Note: Delaware SEPP offers a 50 percent J\&S benefit to all retirees with no reduction in their monthly benefit. In this analysis, this option is classified as a single life annuity. If the retiree requests a higher benefit for the beneficiary, the initial monthly benefit is reduced by a legislated formula. 
Chart 3. Annuity Options Provided by Cash Balance and Hybrid Plans along with DB Plans in States that Allow Choice and Have a DB Plan as One of the Options

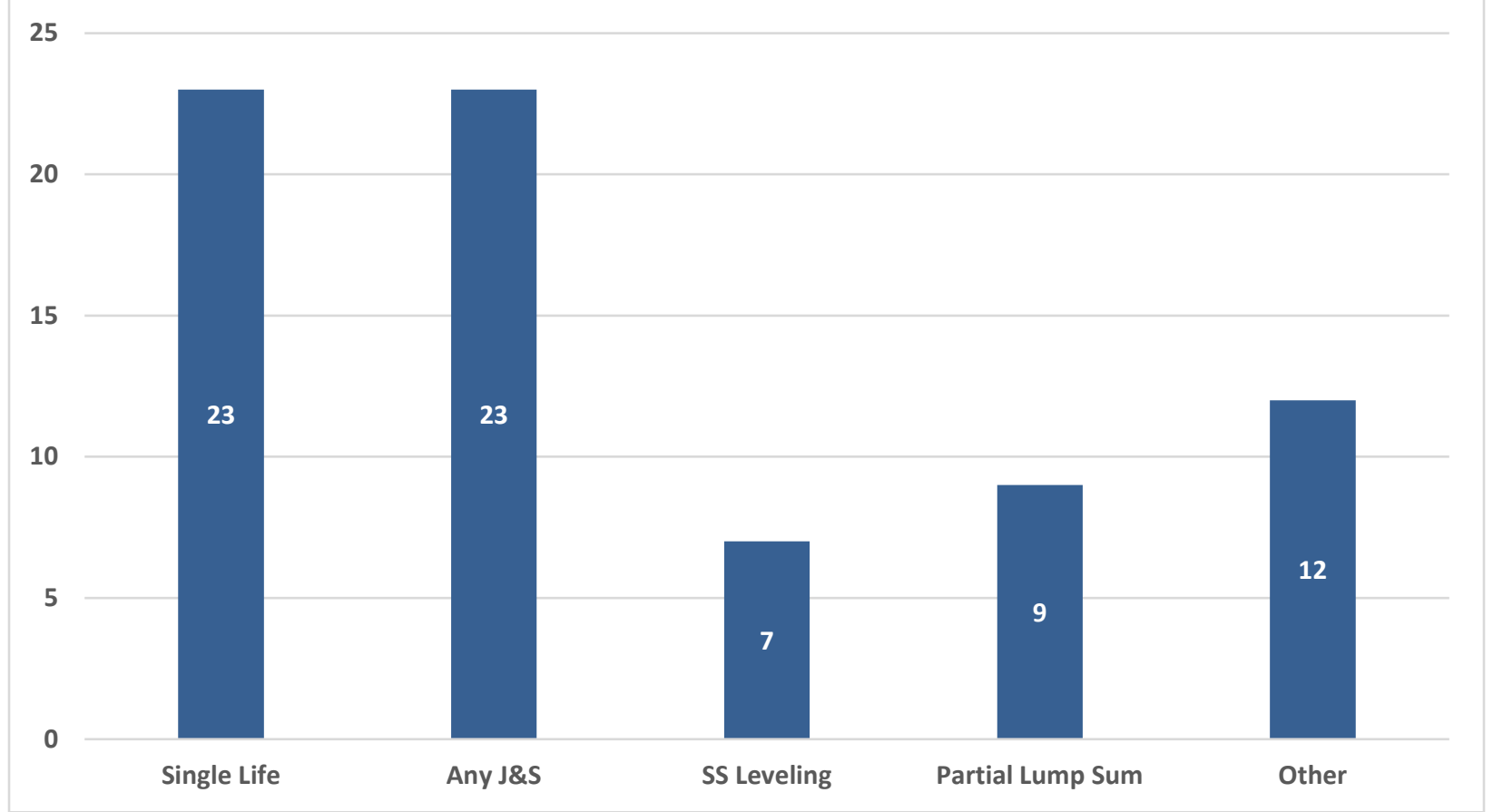

Source: Plan documents describing annuity options are summarized at: https://drive.google.com/file/d/1UwKYbhFrAWxvwu_Db2oOgh5gHUb98kR_/view

Note: The default option for Kansas retirement system is a life annuity for the retiree with 10 years guaranteed payments to a beneficiary if the retiree dies within 10 years. In this paper, this option is classified as a single life annuity option. 
Chart 4. Pricing of Joint and Survivor Benefits for Plans Offering Only Traditional DB Plans

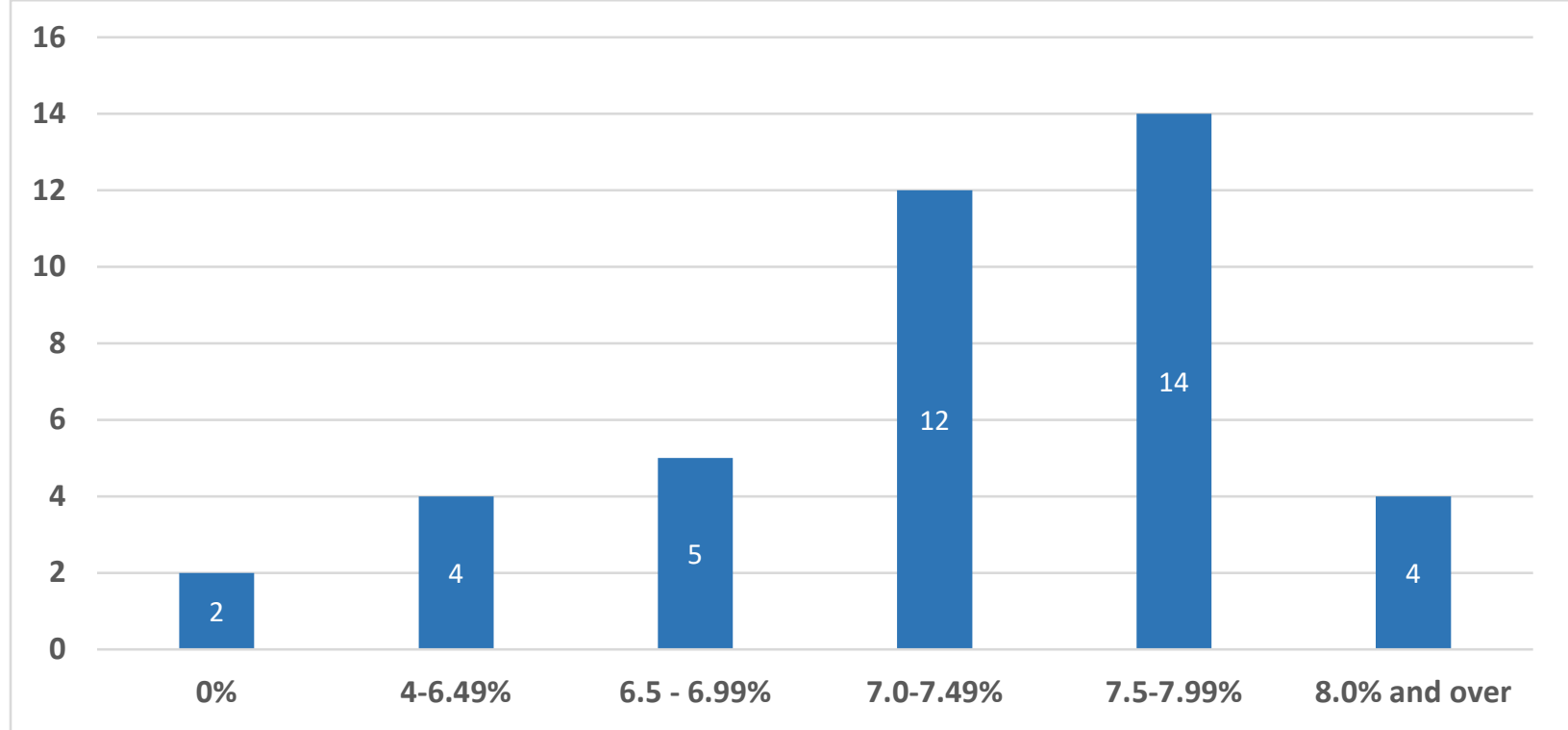

Source: Information provided by each retirement system. See Table 2 for data for each retirement system.

Note: Two retirement systems, Idaho PERS and Delaware SEPP, indicate that the J\&S coverage for a beneficiary is provided for no reduction. 
Chart 5. Pricing of Joint and Survivor Benefits for DB Components of Hybrid Plans and Systems that Offer Choice of Plan Type

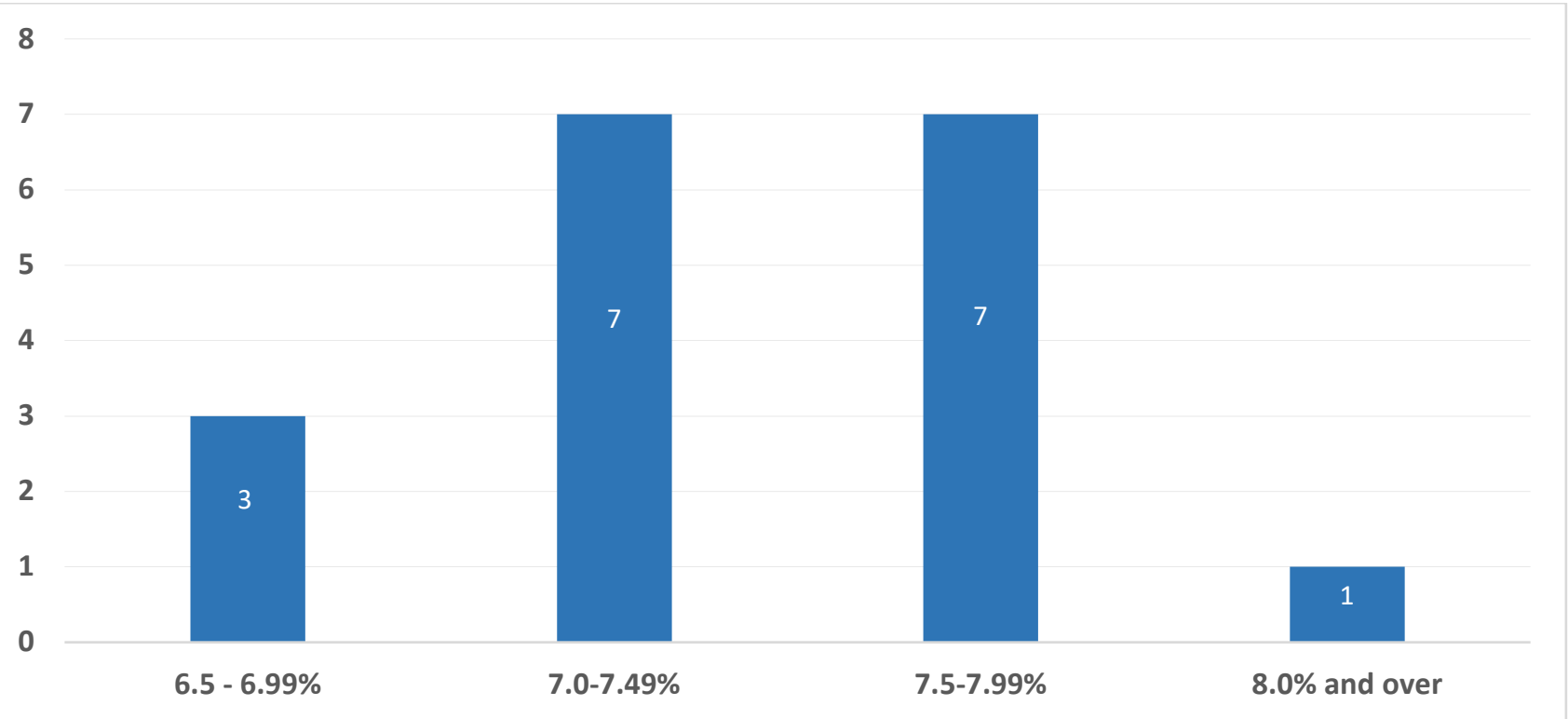

Source: Information provided by each retirement system. See Table 3 for data for each retirement system. 
Table 1. Annuity Options Provided by DC Plans

\begin{tabular}{|c|c|c|c|c|c|c|c|c|c|}
\hline$\#$ & State & $\begin{array}{l}\text { Fund } \\
\text { Name }\end{array}$ & $\begin{array}{l}\text { Plan } \\
\text { Option }\end{array}$ & $\begin{array}{l}\text { Single } \\
\text { Life }\end{array}$ & $\begin{array}{l}\text { Any } \\
\text { J\&S }\end{array}$ & $\begin{array}{l}\text { SS } \\
\text { Leveling }\end{array}$ & $\begin{array}{l}\text { Partial } \\
\text { Lump } \\
\text { Sum }\end{array}$ & Other & Company \\
\hline 1 & Alaska & PERS & DC only & $*$ & & & & & Empower Retirement \\
\hline 2 & Alaska & TRS & DC only & $*$ & & & & & Empower Retirement \\
\hline 3 & Michigan & SERS & DC only & $*$ & & & & & $\begin{array}{l}\text { Voya Financial and the } \\
\text { Michigan Civil Service } \\
\text { Commission }\end{array}$ \\
\hline 4 & Colorado & PERA & DC choice & $*$ & & & & & Voya Financial \\
\hline 5 & Florida & FRS & DC choice & $*$ & & & & & MetLife \\
\hline 6 & Montana & PERS & DC choice & $*$ & & & & & Empower Retirement \\
\hline 7 & $\begin{array}{l}\text { North } \\
\text { Dakota }\end{array}$ & PERS & DC choice & $*$ & & & & & TIAA \\
\hline 8 & Michigan & MERS & DC choice & Yes & Yes & No & No & Yes & $\begin{array}{l}\text { Annuity Options } \\
\text { within the system }\end{array}$ \\
\hline 9 & Michigan & PSERS & DC choice & $*$ & & & & & Income Solutions \\
\hline 10 & Ohio & PERS & DC choice & Yes & Yes & No & Yes & No & $\begin{array}{l}\text { Annuity Options } \\
\text { within the system }\end{array}$ \\
\hline 11 & Ohio & STRS & DC choice & Yes & Yes & No & Yes & No & $\begin{array}{l}\text { Annuity Options } \\
\text { within the system }\end{array}$ \\
\hline 12 & Utah & SRS & DC choice & & & & & & No annuity options \\
\hline
\end{tabular}

Source: Data obtain from each retirement system's webpage.

Note: DC only means that the retirement system offers only a Defined Contribution plan to their employees; DC choice means that the retirement system offers choice among retirement plans including Defined Contribution plan choice. Michigan MERS and Ohio PERS and STRS retirement systems provide annuity options within the retirement system including single life and joint \& survivor options. Utah SRS only allows the retiree to withdraw funds. All DC plans offer retirees to leave funds in the system, roll over funds to another account, either fully or partially in periodic installments withdraw funds as lump sum.

* Retirees in these plans are able to annuitize with the financial service company. 
Table 2. Pricing of Joint and Survivor Benefits for Traditional DB plans

\begin{tabular}{|c|c|c|c|c|}
\hline & State & System & Interest Rate & Rate of Return \\
\hline 1 & Alabama & ERS & $8.00 \%$ & $8.00 \%$ \\
\hline 2 & Alabama & TRS & $8.00 \%$ & $8.00 \%$ \\
\hline 3 & Arizona & SRS & $7.50 \%$ & $8.00 \%$ \\
\hline 4 & Arkansas & PERS & DNR & $7.50 \%$ \\
\hline 5 & Arkansas & TRS & $7.50 \%$ & $7.50 \%$ \\
\hline 6 & California & PERS & $7.00 \%$ & $7.00 \%$ \\
\hline 7 & California & TRS & $7.00 \%$ & $7.00 \%$ \\
\hline 8 & Connecticut & SERS & DNR & $8.00 \%$ \\
\hline 9 & Connecticut & TRS & DNR & $8.50 \%$ \\
\hline 10 & Delaware & SEPP & $\underline{\text { Formula, see notes }}$ & $7.20 \%$ \\
\hline 11 & Georgia & TRS & $7.50 \%$ & $7.50 \%$ \\
\hline 12 & Hawaii & ERS & $7.00 \%$ & $7.00 \%$ \\
\hline 13 & Idaho & PERS & none & $7.50 \%$ \\
\hline 14 & Illinois & SRS & $7.00 \%$ & $7.00 \%$ \\
\hline 15 & Illinois & TRS & DNR & $7.00 \%$ \\
\hline 16 & Illinois & MRF & $7.25 \%$ & $7.50 \%$ \\
\hline 17 & Iowa & PERS & $7.50 \%$ & $7.50 \%$ \\
\hline 18 & Kentucky & TRS & DNR & $7.50 \%$ \\
\hline 19 & Louisiana & SERS & $7.50 \%$ & $7.50 \%$ \\
\hline 20 & Louisiana & TRSL & $7.50 \%$ & $7.70 \%$ \\
\hline 21 & Maine & PERS & DNR & $6.88 \%$ \\
\hline 22 & Maryland & SRPR & $5.85 \%$ & $7.55 \%$ \\
\hline 23 & Massachusetts & SERS & $7.00 \%$ & $7.50 \%$ \\
\hline 24 & Massachusetts & TRS & $7.00 \%$ & $7.50 \%$ \\
\hline 25 & Minnesota & MSRS & $6.50 \%$ & $7.50 \%$ \\
\hline 26 & Minnesota & PERA & $6.93 \%$ & $7.50 \%$ \\
\hline 27 & Minnesota & TRA & $6.50 \%$ & $8.00 \%$ \\
\hline 28 & Mississippi & PERS & $7.75 \%$ & $7.75 \%$ \\
\hline 29 & Missouri & SERS & Formula, see notes & $7.65 \%$ \\
\hline 30 & Missouri & LAGERS & $7.25 \%$ & $7.25 \%$ \\
\hline 31 & Missouri & PSRS & DNR & $7.75 \%$ \\
\hline 32 & Montana & TRS & $7.75 \%$ & $7.75 \%$ \\
\hline 33 & Nebraska & SPP & DNR & $8.00 \%$ \\
\hline 34 & Nevada & PERS & $6.50 \%$ & $8.00 \%$ \\
\hline 35 & New Hampshire & NHRS & $7.25 \%$ & $7.25 \%$ \\
\hline 36 & New Jersey & PERS & DNR & $7.65 \%$ \\
\hline 37 & New Jersey & TPAF & DNR & $7.65 \%$ \\
\hline 38 & New Mexico & PERA & $8.00 \%$ & $7.48 \%$ \\
\hline 39 & New Mexico & ERA & $7.75 \%$ & $7.75 \%$ \\
\hline 40 & New York & ERS & $6.60 \%$ & $7.50 \%$ \\
\hline 41 & New York & TRS & $7.00 \%$ & $7.50 \%$ \\
\hline 42 & North Carolina & TSERS & $7.25 \%$ & $7.25 \%$ \\
\hline 43 & North Carolina & LGERS & $7.25 \%$ & $7.25 \%$ \\
\hline
\end{tabular}




$\begin{array}{lllcc}44 & \text { North Dakota } & \text { TRF } & 7.75 \% & 7.75 \% \\ 45 & \text { Oklahoma } & \text { PERS } & \text { DNR } & 7.50 \% \\ 46 & \text { Oklahoma } & \text { TRS } & 7.50 \% & 7.50 \% \\ 47 & \text { Pennsylvania } & \text { SERS } & \text { DNR } & 7.50 \% \\ 48 & \text { Pennsylvania } & \text { PSERS } & 4.00 \% & 7.50 \% \\ 49 & \text { South Carolina } & \text { SCRS } & 7.50 \% & 7.50 \% \\ 50 & \text { South Dakota } & \text { SRS } & 6.50 \% & 7.50 \% \\ 51 & \text { Texas } & \text { ERS } & 7.50 \% & 8.00 \% \\ 52 & \text { Texas } & \text { TRS } & 8.00 \% & 8.00 \% \\ 53 & \text { Texas } & \text { MRS } & 5.00 \% & 6.75 \% \\ 54 & \text { Vermont } & \text { SRS } & \text { DNR } & 7.95 \% \\ 55 & \text { Vermont } & \text { TRS } & \text { DNR } & 7.95 \% \\ 56 & \text { West Virginia } & \text { PERS } & \text { DNR } & 7.50 \% \\ 57 & \text { West Virginia } & \text { TRS } & \text { DNR } & 7.50 \% \\ 58 & \text { Wyoming } & \text { WRS } & 7.50 \% & 7.75 \% \\ 59 & \text { Wisconsin } & \text { WRS } & 5.00 \% & 7.20 \% \\ & & & & \end{array}$

Source: Data provided by each retirement system, their CAFRAs, and personal correspondence.

Note: DNR denotes that the retirement system did not respond to our request for information. 
Table 3. Pricing of Joint and Survivor Benefits for Cash Balance and Hybrid Plans and the DB Component of Plans that Allow a Choice

\begin{tabular}{lllccc}
\hline \# & State & System & $\begin{array}{c}\text { Plan } \\
\text { Option }\end{array}$ & $\begin{array}{c}\text { Interest } \\
\text { Rate }\end{array}$ & $\begin{array}{c}\text { Rate of } \\
\text { Return }\end{array}$ \\
\hline 1 & Colorado & PERA & Hybrid & $7.25 \%$ & $7.25 \%$ \\
2 & Florida & FRS & Hybrid & $7.65 \%$ & $7.65 \%$ \\
3 & Georgia & ERS & Hybrid & $7.40 \%$ & $7.50 \%$ \\
4 & Indiana & PERF & Hybrid & $6.75 \%$ & $6.75 \%$ \\
5 & Indiana & TRF & Hybrid & $6.75 \%$ & $6.75 \%$ \\
6 & Kansas & PERS & Hybrid & $7.75 \%$ & $8.00 \%$ \\
7 & Kentucky & KERS & CB & $7.50 \%$ & $7.50 \%$ \\
8 & Kentucky & CERS & CB & $7.25 \%$ & $7.50 \%$ \\
9 & Michigan & MERS & CB & DNR & $7.75 \%$ \\
10 & Michigan & PSERS & CB & $8.00 \%$ & $8.00 \%$ \\
11 & Montana & PERS & CB & DNR & $7.75 \%$ \\
12 & Nebraska & SEPP & DBorDC & DNR & $7.75 \%$ \\
13 & Nebraska & CEPP & DBorDC & DNR & $7.75 \%$ \\
14 & North Dakota & PERS & DBorDC & DNR & $8.00 \%$ \\
15 & Ohio & PERS & DBorDC & $7.50 \%$ & $8.00 \%$ \\
16 & Ohio & STRS & Choice & $7.45 \%$ & $7.45 \%$ \\
17 & Oregon & PERS & Choice & $7.20 \%$ & $7.50 \%$ \\
18 & Rhode Island & ERS & Choice & $7.50 \%$ & $7.50 \%$ \\
19 & Tennessee & CRS & Choice & $7.25 \%$ & $7.25 \%$ \\
20 & Utah & SRS & Choice & $6.95 \%$ & $7.20 \%$ \\
21 & Virginia & SRS & Choice & $7.00 \%$ & $7.00 \%$ \\
22 & Washington & PERS & Choice & $7.70 \%$ & $7.50 \%$ \\
23 & Washington & TRS & Choice & $7.70 \%$ & $7.50 \%$ \\
\hline
\end{tabular}

Source: Data provided by each retirement system and their CAFRAs.

Note: DNR denotes the retirement system did not respond to our requests for information. 
Table 4. J\&S Option Benefit Amounts: Public School Teachers

Panel A. J\&S 100\% option benefit, assuming \$1,000 monthly single life benefit; $8 \%$ interest; teacher mortality; $65 \%$ of retirees and $50 \%$ of beneficiaries are female

\section{Age of beneficiary}

\begin{tabular}{cccc} 
Age of benefit claimant & 50 & 60 & 70 \\
\hline 50 & $\$ 967$ & $\$ 979$ & $\$ 989$ \\
60 & $\$ 914$ & $\$ 941$ & $\$ 967$ \\
70 & $\$ 801$ & $\$ 844$ & $\$ 901$
\end{tabular}

Panel B. J\&S $100 \%$ option benefit, assuming \$1,000 monthly single life benefit; $4 \%$ interest; teacher mortality; $65 \%$ of retirees and $50 \%$ of beneficiaries are female

\section{Age of beneficiary}

\begin{tabular}{cccc} 
Age of benefit claimant & 50 & 60 & 70 \\
\hline 50 & $\$ 941$ & $\$ 970$ & $\$ 987$ \\
60 & $\$ 855$ & $\$ 914$ & $\$ 960$ \\
70 & $\$ 698$ & $\$ 780$ & $\$ 875$ \\
\hline
\end{tabular}

These calculations use mortality tables for the specified retiree group and contingent survivors from the headcount-weighted rates in the exposure draft of the Pub-2010 Public Retirement Plans Mortality Tables released by the Society of Actuaries (https://www.soa.org/experiencestudies/2018/pub-2010-retirement-plans/), projected generationally using Scale MP-2017 assuming a retirement date in 2018. 
Table 5. J\&S Option Benefit Amounts: Public Safety Workers

Panel A. J\&S 100\% option benefit, assuming \$1,000 monthly single life benefit; $8 \%$ interest; public safety worker mortality; $10 \%$ of retirees and $90 \%$ of beneficiaries are female

$\underline{\text { Age of beneficiary }}$

\begin{tabular}{cccc} 
Age of benefit claimant & 50 & 60 & 70 \\
\hline 50 & $\$ 940$ & $\$ 959$ & $\$ 977$ \\
60 & $\$ 862$ & $\$ 896$ & $\$ 935$ \\
70 & $\$ 722$ & $\$ 766$ & $\$ 833$ \\
\hline
\end{tabular}

Panel B. J\&S 100\% option benefit, assuming \$1,000 monthly single life benefit; 4\% interest; public safety worker mortality; $10 \%$ of retirees and $90 \%$ of beneficiaries are female

$\underline{\text { Age of beneficiary }}$

\begin{tabular}{cccc} 
Age of benefit claimant & 50 & 60 & 70 \\
\hline 50 & $\$ 899$ & $\$ 942$ & $\$ 973$ \\
60 & $\$ 781$ & $\$ 851$ & $\$ 921$ \\
70 & $\$ 606$ & $\$ 684$ & $\$ 792$ \\
\hline
\end{tabular}

These calculations use mortality tables for the specified retiree group and contingent survivors from the headcount-weighted rates in the exposure draft of the Pub-2010 Public Retirement Plans Mortality Tables released by the Society of Actuaries (https://www.soa.org/experiencestudies/2018/pub-2010-retirement-plans/), projected generationally using Scale MP-2017 assuming a retirement date in 2018. 
Table 6. Percent of Retirees Selecting a J\&S Annuity and Interest Rate Used to Price the Benefit

\begin{tabular}{llll}
\hline State & System & Percent J\&S & Interest Rate \\
\hline California & PERS & 37.3 & 7.0 \\
California & TRS & 46.9 & 7.0 \\
Delaware & SEPP & 100.0 & No Reduction for J\&S \\
Iowa & PERS & 38.2 & 7.50 \\
Maryland & SRPS & 34.0 & 5.85 \\
Mississippi & PERS & 22.0 & 7.75 \\
North Carolina & TSERS & 25.9 & 7.25 \\
North Carolina & LGERS & 34.6 & 7.25 \\
South Carolina & SCRS & 30.4 & 7.50 \\
Washington & PERS & 34.8 & 7.70 \\
Washington & TRS & 21.4 & 7.70 \\
Wyoming & WRS & 52.9 & 7.50 \\
\hline
\end{tabular}

Source: Clark and Cowell (2017) and information shown in Tables 2 and 3. 


\section{References}

Aura, Saku. 2005. "Does the balance of power within a family matter? The case of the retirement equity act,” Journal of Public Economics, 89: 1699-1717.

Benatzi, Shlomo, Alessandro Previtero, and Richard Thaler. 2011. “Annuitization puzzles,” Journal of Economic Perspectives, 25(4): 143-164.

Brown, Jeffrey. 2001. “Private pensions, mortality risks, and the decision to annuitize,” Journal of Public Economics, 82(1): 29-62.

Brown, Jeffrey, J.R. Kling, S. Mullainathan, and M.V. Wrobel. 2008. “Why don’t People Insure Late-Life Consumption? A Framing Explanation of the Under-Annuitization Puzzle,” American Economic Review: Papers \& Proceedings, 98(2): 304-309.

Brown, Jeffrey and James Poterba. 2000 "Joint life annuities and annuity demand by married couples," Journal of Risk and Insurance, December: 527-553.

Butler, M and F. Teppa. 2007. “The choice between an annuity and a lump sum: Results from Swiss pension funds,” Journal of Public Economics, 91(10):1944-1966.

Chalmers, J. and J. Reuter. 2012. "How do retirees value life annuities? Evidence from public employees,” The Review of Financial Studies, 25:8): 2601-2634.

Clark, Robert and Janet Cowell. 2017. “Annuity Options in Public Pension Plans,” in Financial Decision Making and Retirement Security in an Aging World, Olivia Mitchell, Brett Hammond, and Stephen Utkus (eds.), Oxford, UK: Oxford University Press 2017, pp. 130-152.

Clark, R. L., Hammond, R. G., Morrill, M. S., and Vanderweide, D. 2018. “Annuity Options in Public Pension Plans: The Curious Case of Social Security Leveling,” Journal of Retirement, Summer, 6(1): 33-44.

Clark, Robert, Robert Hammond, and David Vanderweide. 2019 forthcoming. "Navigating 
Complex Financial Decisions at Retirement: Evidence from Annuity Choices in Public Sector Pensions,” Journal of Pension Economics and Finance..

Clark, Robert, Melinda Morrill, and David Vanderweide. 2014. “Defined Benefit Pension Plan Distribution Decisions by Public Sector Employees" Journal of Public Economics, August, 116: 73-88.

Clark, Robert, Aditi Pathak, and Denis Pelletier, "Supplemental Retirement Savings Plans in the Public Sector: Participation and Contribution Decisions by School Personnel,” Journal of Journal of Labor Research, December 2018, 39(4): 383-404. .

Clark, Robert and Sylvester Schieber. 2004. “Adopting Cash Balance Pension Plans: Implications and Issues," Journal of Pension Economics and Finance, November: 271295.

Holden, K. and Nicholson, S., 1998. "Selection of a joint-and-survivor pension.” Institute for Research on Poverty Discussion Paper No. 1175-98.

Johnson, Richard, Cori Uccello, and Joshua Goldwyn. 2005. "Who Foregoes Survivor Protection in Employer-Sponsored Annuities,” The Gerontologist, 45(1): 26-35.

McGill, Dan, Kyle Brown, John Haley, Sylvester Schieber, and Mark Warshawsky. 2010. Fundamentals of Private Pensions, Oxford University Press, Oxford UK.

Wisconsin Legislative Council. 2016. “2015 Comparative Study of Major Public Pension Systems, https://docs.legis.wisconsin.gov/misc/lc/comparative_retirement_study/2015_retirement. pdf 
Appendix Table 1. Annuity Options Provided by State and Local Systems Providing Only Traditional DB Plans

\begin{tabular}{|c|c|c|c|c|c|c|c|}
\hline & State & $\begin{array}{l}\text { Fund } \\
\text { Name }\end{array}$ & Single Life & $\begin{array}{l}\text { Any } \\
\text { J\&S }\end{array}$ & $\begin{array}{c}\text { SS } \\
\text { Leveling }\end{array}$ & $\begin{array}{c}\text { Partial Lump } \\
\text { Sum }\end{array}$ & Other \\
\hline 1 & Alabama & ERS & Yes & Yes & No & No & No \\
\hline 2 & Alabama & TRS & Yes & Yes & No & No & No \\
\hline 3 & Arizona & SRS & Yes & Yes & No & Yes & Yes \\
\hline 4 & Arkansas & PERS & Yes & Yes & No & Yes & Yes \\
\hline 5 & Arkansas & TRS & Yes & Yes & No & No & Yes \\
\hline 6 & California & PERS & Yes & Yes & No & No & No \\
\hline 7 & California & TRS & Yes & Yes & No & No & No \\
\hline 8 & Connecticut & SERS & Yes & Yes & No & No & Yes \\
\hline 9 & Connecticut & TRS & Yes & Yes & No & No & Yes \\
\hline 10 & Delaware & SEPP & Yes & Yes & No & No & No \\
\hline 11 & Georgia & TRS & Yes & Yes & No & Yes & No \\
\hline 12 & Hawaii & ERS & Yes & Yes & No & Yes & Yes \\
\hline 13 & Idaho & PERS & Yes & Yes & Yes & No & Yes \\
\hline 14 & Illinois & SRS & Yes & Yes & Yes & No & No \\
\hline 15 & Illinois & TRS & Yes & Yes & No & No & No \\
\hline 16 & Illinois & MRF & Yes & Yes & No & No & No \\
\hline 17 & Iowa & PERS & Yes & Yes & No & No & Yes \\
\hline 18 & Kentucky & TRS & Yes & Yes & No & No & Yes \\
\hline 19 & Louisiana & SERS & Yes & Yes & No & Yes & No \\
\hline 20 & Louisiana & TRSL & Yes & Yes & No & Yes & No \\
\hline 21 & Maine & PERS & Yes & Yes & No & No & Yes \\
\hline 22 & Maryland & SRPR & Yes & Yes & No & No & Yes \\
\hline 23 & Massachusetts & SERS & Yes & Yes & No & No & No \\
\hline 24 & Massachusetts & TRS & Yes & Yes & No & No & No \\
\hline 25 & Minnesota & MSRS & Yes & Yes & No & No & Yes \\
\hline 26 & Minnesota & PERA & Yes & Yes & No & No & No \\
\hline 27 & Minnesota & TRA & Yes & Yes & No & No & Yes \\
\hline 28 & Mississippi & PERS & Yes & Yes & No & Yes & Yes \\
\hline 29 & Missouri & SERS & Yes & Yes & No & No & Yes \\
\hline 30 & Missouri & LAGERS & Yes & Yes & No & Yes & Yes \\
\hline 31 & Missouri & PSRS & Yes & Yes & No & Yes & Yes \\
\hline 32 & Montana & TRS & Yes & Yes & No & No & Yes \\
\hline 33 & Nebraska & SPP & Yes & Yes & No & No & Yes \\
\hline 34 & $\begin{array}{l}\text { Nevada } \\
\text { New }\end{array}$ & PERS & Yes & Yes & No & No & No \\
\hline 35 & Hampshire & NHRS & Yes & Yes & No & No & Yes \\
\hline 36 & New Jersey & PERS & Yes & Yes & No & No & Yes \\
\hline 37 & New Jersey & TPAF & Yes & Yes & No & No & Yes \\
\hline 38 & New Mexico & PERA & Yes & Yes & No & No & No \\
\hline 39 & New Mexico & ERA & Yes & Yes & No & No & No \\
\hline 40 & New York & ERS & Yes & Yes & No & No & Yes \\
\hline
\end{tabular}




\begin{tabular}{|c|c|c|c|c|c|c|c|}
\hline 41 & New York & TRS & Yes & Yes & No & No & Yes \\
\hline 42 & North Carolina & TSERS & Yes & Yes & Yes & No & Yes \\
\hline 43 & North Carolina & LGERS & Yes & Yes & Yes & No & Yes \\
\hline 44 & North Dakota & TRF & Yes & Yes & Yes & Yes & Yes \\
\hline 45 & Oklahoma & PERS & Yes & Yes & No & No & Yes \\
\hline 46 & Oklahoma & TRS & Yes & Yes & No & Yes & Yes \\
\hline 47 & Pennsylvania & SERS & Yes & Yes & No & No & Yes \\
\hline 48 & Pennsylvania & PSERS & Yes & Yes & No & No & Yes \\
\hline 49 & South Carolina & SCRS & Yes & Yes & No & No & No \\
\hline 50 & South Dakota & SRS & Yes & Yes & No & Yes & No \\
\hline 51 & Texas & ERS & Yes & Yes & No & Yes & Yes \\
\hline 52 & Texas & TRS & Yes & Yes & No & Yes & Yes \\
\hline 53 & Texas & MRS & Yes & Yes & No & Yes & Yes \\
\hline 54 & Vermont & SRS & Yes & Yes & Yes & No & No \\
\hline 55 & Vermont & TRS & Yes & Yes & No & No & No \\
\hline 56 & West Virginia & PERS & Yes & Yes & No & No & No \\
\hline 57 & West Virginia & TRS & Yes & Yes & No & No & Yes \\
\hline 58 & Wyoming & WRS & Yes & Yes & No & No & Yes \\
\hline 59 & Wisconsin & WRS & Yes & Yes & Yes & Yes & Yes \\
\hline
\end{tabular}


Appendix Table 2. Annuity Options Provided by Cash Balance and Hybrid Plans along with DB Plans in States that Allow Choice and Have a DB Plan as One of the Options

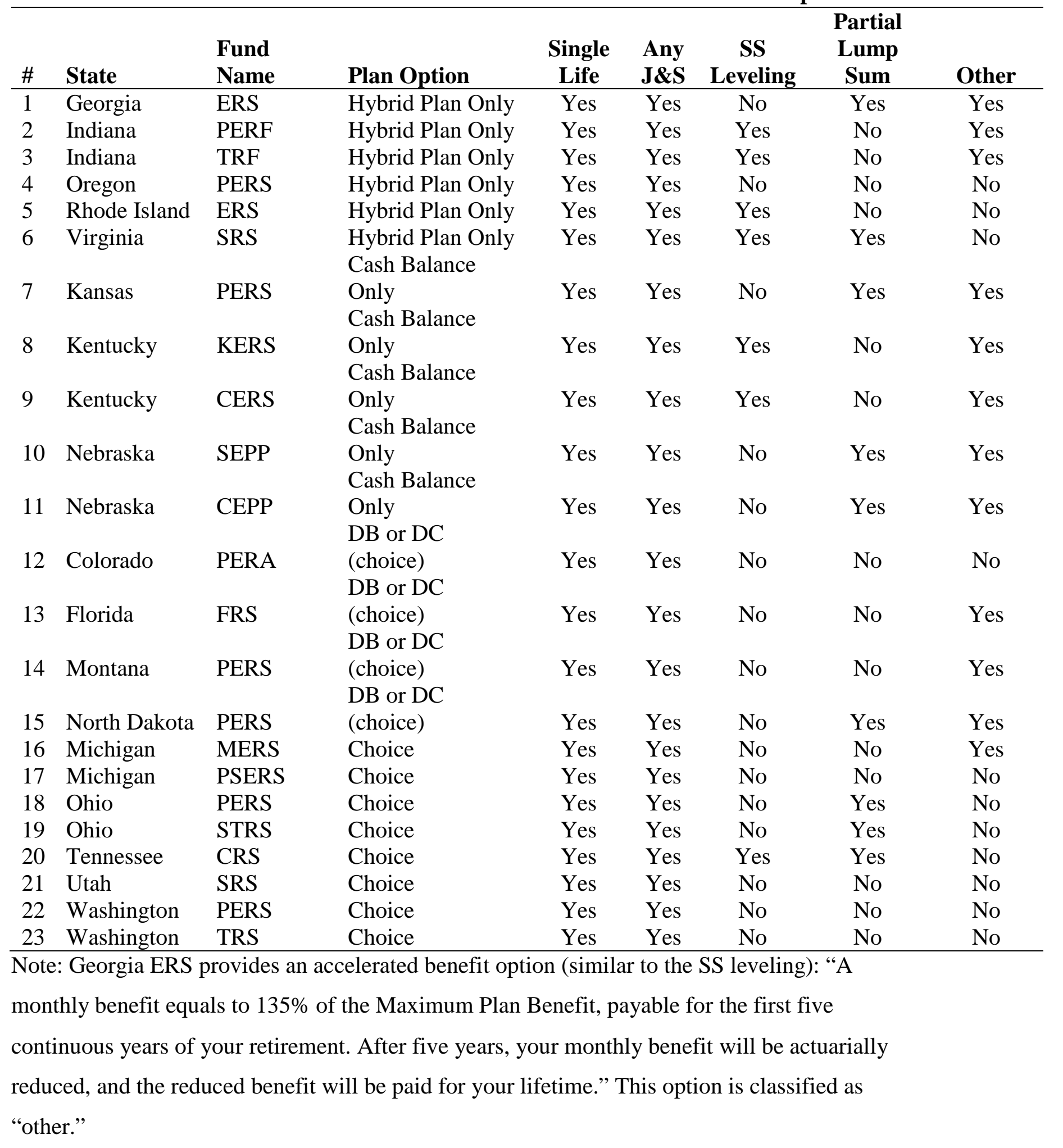

